\title{
Gnomoniopsis smithogilvyi: identification, characterization and incidence of the main pathogen causing brown rot in postharvest sweet chestnut fruits (Castanea sativa) in Chile
}

\author{
Viviana Cisterna-Oyarce ${ }^{1}$. Jorge Carrasco-Fernández ${ }^{1}$. Jean Franco Castro ${ }^{1}\left[\right.$ Cecilia Santelices $^{1}$. \\ Violeta Muñoz-Reyes ${ }^{1} \cdot$ Paz Millas $^{1} \cdot$ Alan G. Buddie $^{2} \cdot$ Andrés France $^{1}$
}

Received: 17 December 2021 / Accepted: 27 January 2022 / Published online: 31 January 2022

(c) The Author(s) under exclusive licence to Australasian Plant Pathology Society Inc. 2022

\begin{abstract}
We describe the first identification of Gnomoniopsis smithogilvyi causing brown rot on chestnut fruits in Chile, with an incidence of 4.8\%. Previously, Phomopsis castanea (IMI 278057) was reported as the cause of the disease in Chile, but a molecular re-identification revealed that it corresponded to G. smithogilvyi. All chestnut fruits inoculated with the isolate G. smithogilvyi RGM 2903 developed brown rot symptoms on fruits.
\end{abstract}

Keywords Sweet chestnut $\cdot$ Incidence $\cdot$ Postharvest disease $\cdot$ Phomopsis castanea

The relative occurrence of brown rot in sweet chestnut fruits (Castanea sativa) was evaluated during March to August 2018 to 2020, in Chile. A total of 31851 fruits, from the cultivars: Bouche Rouge, Marrone di Castel Borello, Marrone di Chiusa Pesio, Marrone di Città di Castello, Marrone di Cuneo, Marrone di Marradi, and Marrone di Val di Susa were collected from two packing houses located in Nuble, Chile, representing orchards in the center-south growing areas. Asymptomatic fruits were surface sterilized in $70 \%(\mathrm{v} / \mathrm{v})$ ethanol for $1 \mathrm{~min}$, cut in halves, and incubated in moist chambers $(5 \mathrm{~d})$ at $24{ }^{\circ} \mathrm{C}$ under light-darkness cycles of 12:12 h. After incubation, kernel tissues that developed brown rot and white to brown mummification (Fig. 1A) and light-brown cirri emerging from the acervuli (Fig. 1B) were cultured on potato dextrose agar (Difco $\left.{ }^{\mathrm{TM}} \mathrm{PDA}\right)$ and incubated at $24{ }^{\circ} \mathrm{C}$ for $7 \mathrm{~d}$. On PDA, cultures grew as white cottony colonies with concentric rings that turned yellowish over time (Fig. 1C); black conidiomata (158-200 $\mu \mathrm{m})$ (Fig. 1D) and ellipsoidal hyaline conidia of $6.3 \pm 0.6$ $(5.3-7.8) \times 2.5 \pm 0.3(1.9-2.9) \mu \mathrm{m}$ (Fig. 1E) were exuded in gelatinous matrices forming light-brown cirri on the colony

Jean Franco Castro

jean.castro@inia.cl

1 Instituto de Investigaciones Agropecuarias (INIA), Av. Vicente Méndez 515, Chillán, Nuble, Chile

2 CABI, Bakeham Lane, Egham, Surrey TW20 9TY, UK surface. These characters agree with the morphological descriptions for G. smithogilvyi Shuttlew (Synon. Gnomoniopsis castaneae Tamietti) (Maresi et al. 2013; Lione et al. 2019; Shuttleworth et al. 2012, 2018). The average incidence of this postharvest pathogen among cultivars in Chile was $4.8 \%$ (Table 1). Similar studies carried out in other countries point to wide variability in that there is a wide variability in the incidence of brown rot caused by $G$. smithogilvyi (reported as G. castaneae), ranging from from $3-93 \%$, varying with the orchard and year of evaluation and influenced by climatic conditions, such as the maximum or average monthly temperatures (Dennert et al. 2015; Lione et al. 2015; Shuttleworth et al. 2013).

Two representative isolates from this study were deposited in the Chilean Collection of Microbial Genetic Resources (CChRGM) and registered with the collection codes RGM 2903 and RGM 2904. Molecular identification of these isolates was carried out by isolating their genomic DNA using the Wizard ${ }^{\circledR}$ Genomic DNA Purification Kit (Promega), followed by sequencing of the ITS and EF- $1 \alpha$ DNA regions with primers ITS1/ITS 4 (White et al. 1990) for ITS and EF1-728F (Carbone and Kohn 1999) and EF2 (O'Donnell et al. 1998) for EF-1 $\alpha$. Sequencing was performed at Macrogen (Seoul, Republic of Korea). Sequences were assessed for quality and consensus sequences assembled using Sequencher v5.4.6 software (Gene Codes Corporation, MI) and submitted to GenBank (ITS: MT413428-MT413429; EF-1 $\alpha$ : 


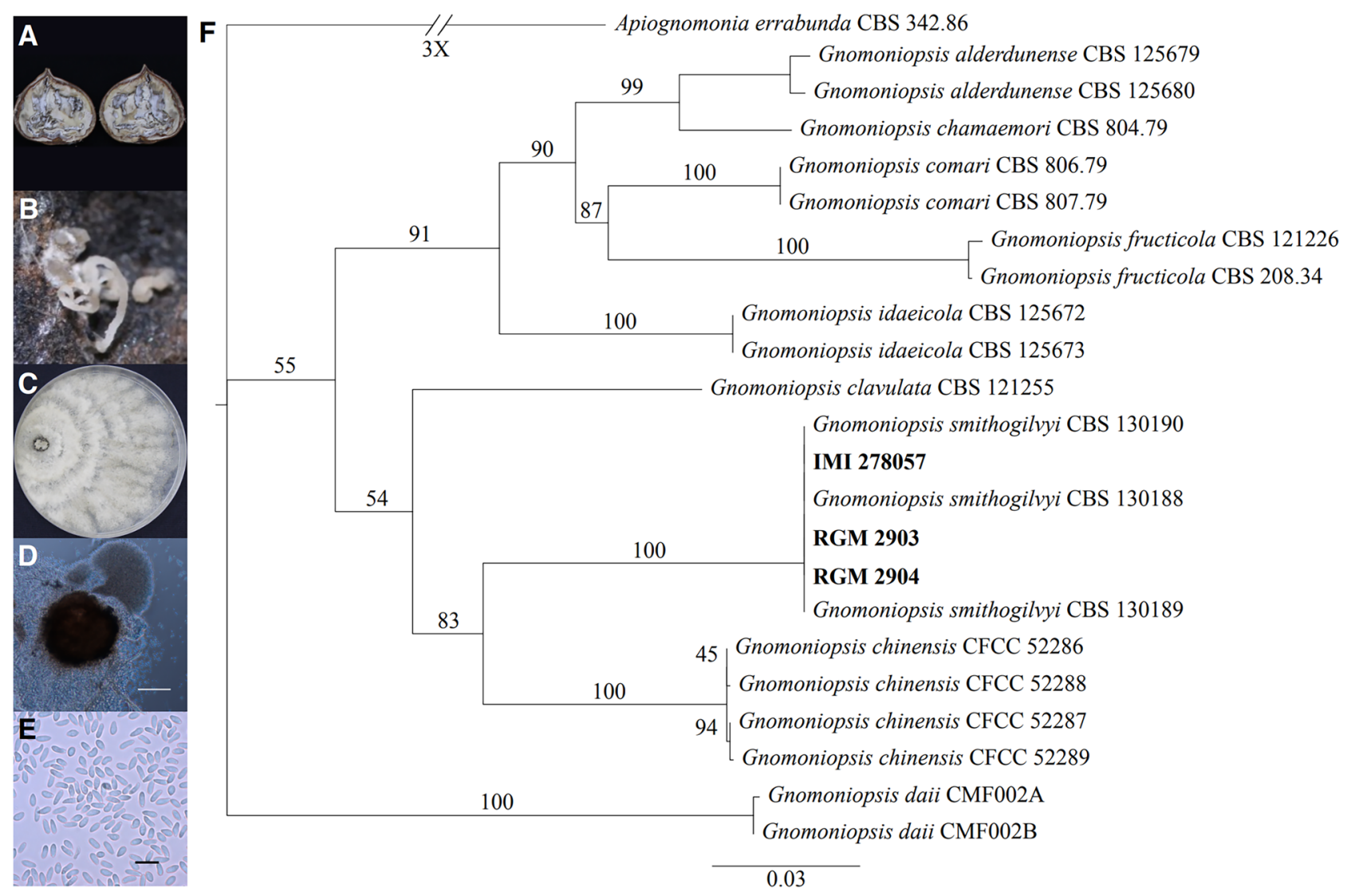

Fig. 1 Isolation and identification of Gnomoniopsis smithogilvyi from sweet chestnut fruits in packing houses in Nuble Region, Chile. (A) fruits showing brown rot; (B) cirrus emerging from fruits; (C) colony of Gnomoniopsis smithogilvyi RGM 2903 growing on PDA; (D) microscopic observation of an acervulus showing conidia exudates $(40 \times$ magnification; bar $=100 \mu \mathrm{m}) ;(\mathbf{E})$ microscopic observation of conidia $(100 \times$ magnification; bar $=10 \mu \mathrm{m}) ;(\mathbf{F})$ phylogenetic tree

MT435530-MT435531, respectively). The consensus tree was obtained from a maximum likelihood analysis in the IQ-TREE webserver (Trifinopoulos et al. 2016) using concatenated sequence data from the ITS and EF-1 $\alpha$ DNA regions for the Gnomoniopsis isolates and those of the reference strains (Dennert et al. 2015). The substitution model was set in automatic for each partition dataset (ITS and EF-1 $\alpha$ ) and the analysis was run with 1000 ultrafast bootstrap replicates (substitution model for each partition resulting from a maximum likelihood analysis of combined sequence data from ITS and EF-1 $\alpha$ DNA regions for Gnomoniopsis species; numbers in the nodes represent ultrafast bootstrap values. The strain Phomopsis castanea described by Montealegre and González (1986) was reported in their publication with the code IMI 278059, which has a typographical error. The correct code according to CABI is IMI 278057 , which was used throughout this work

was ITS: $\mathrm{K} 2 \mathrm{P}+\mathrm{I}$ and $\mathrm{EF}-1 \alpha$ : TIM2 $+\mathrm{F}+\mathrm{G} 4)$. Both isolates grouped together with G. smithogilvyi CBS 130190 (ex-type) in a single clade, showing $100 \%$ of ultrafast bootstrap support in the maximum likelihood-derived tree. Thus, morphological and molecular information confirmed the affiliation of strains RGM 2903 and RGM 2904 to $G$. smithogilvyi species (Fig. 1F), making the first identification of this species in Chile. However, this is not the first report of this postharvest pathogen.

Table 1 Incidence of the postharvest pathogen Gnomoniopsis smithogilvyi on seven cultivars of chestnut fruits from packing houses of Nuble Region, Chile

\begin{tabular}{|c|c|c|c|c|c|c|c|c|}
\hline & \multicolumn{7}{|l|}{ Chestnut cultivar } & \multirow[b]{2}{*}{ Total } \\
\hline & Bouche Rouge & $\begin{array}{l}\text { M. di Castel } \\
\text { Borello }\end{array}$ & $\begin{array}{l}\text { M. di Chiusa } \\
\text { di Pesio }\end{array}$ & $\begin{array}{l}\text { M. di Città di } \\
\text { Castello }\end{array}$ & M. di Cuneo & M. di Marradi & $\begin{array}{l}\text { M. di Val } \\
\text { di Susa }\end{array}$ & \\
\hline $\mathrm{N}^{\circ}$ fruits analyzed & 2430 & 5849 & 2245 & 4417 & 8356 & 3594 & 4960 & 31851 \\
\hline Incidence (\%) & 3.7 & 4.1 & 5.6 & 4.6 & 6.5 & 4.7 & 4.4 & $4.8^{*}$ \\
\hline
\end{tabular}

*Average incidence 
Previously, Phomopsis castanea Sacc. was determined as the causal agent of brown rot symptoms on sweet chestnut fruits in Chile (Montealegre and González 1986), but due to the similarity of the symptoms caused by $P$. castanea (Washington et al. 1999) and G. smithogilvyi, there was confusion about which was the main causal agent of brown nut rot (Smith and Ogilvy 2008; Maresi et al. 2013). The isolate of $P$. castanea reported by Montealegre and González (1986) was morphologically identified and deposited under the code IMI 278057 in the CABI culture collection (Surrey, UK). It remained there for 35 years without further revision of its taxonomical affiliation until this present study. The ITS region of IMI 278057 was sequenced with primers TW81/AB28 (Curran et al. 1994) and the nucleotide sequence (MZ854073) showed 100\% identity with each of the G. smithogilvyi strains obtained in this work (RGM 2903 and RGM 2904). It also had phylogenetic relationships with G. smithogilvyi species in a single clade with $100 \%$ of ultrafast bootstrap support (Fig. 1F) and consequently was re-identified as $G$. smithogilvyi.

Pathogenicity testing was undertaken on thirty asymptomatic sweet chestnut fruits collected directly from sweet chestnut trees in Santa Rosa Experimental Station, Chillán, Chile. The fruits were inoculated with a single disk $(1 \mathrm{~mm}$ diameter) of freshly growing mycelium which was excised from a 7-day-old PDA culture of the strain RGM 2903. This was inserted in an artificial wound made with a sterile metal cork borer in the insertion zone between the peduncle and involucre. Inoculated fruits were incubated for $7 \mathrm{~d}$ at $25^{\circ} \mathrm{C}$ in the dark. As a control, 20 fruits were treated similarly, but using $1 \mathrm{~mm}$ disks of sterile PDA. Only fruits inoculated with strain RGM 2903 presented brown rot symptoms when examined after 7 days, whilst the control did not. It was possible to re-isolate the fungus from all inoculated fruits. Morphological characteristics of the colonies and conidial morphology were identical to the strain RGM 2903.

In this work, we have reported the average incidence of the postharvest pathogen Gnomoniopsis smithogilvyi on seven cultivars of chestnut (Castanea sativa) during a threeyear survey, confirmed the presence of G. smithogilvyi as the causal agent of brown rot in sweet chestnut fruits in storage in Chile, and reassessed the taxonomic position of the strain IMI 278057 by molecular means, thereby identifying it as G. smithogilvyi.

Acknowledgements Authors acknowledge the FONDEQUIP Program from the Chilean National Agency for Research and Development (ANID) (Grant: EQM200205) for funding a platform of equipment for preservation of microbial genetic resources.

\section{References}

Carbone I, Kohn LM (1999) A method for designing primer sets for speciation studies in filamentous ascomycetes. Mycologia 91(3):553-556. https://doi.org/10.1080/00275514.1999.12061051

Curran J, Driver F, Ballard JWO, Milner RJ (1994) Phylogeny of Metarhizium: analysis of ribosomal DNA sequence data. Mycol Res 98(5):547-552. https://doi.org/10.1016/S0953-7562(09) 80478-4

Dennert FG, Broggini GAL, Gessler C, Storari M (2015) Gnomoniopsis castanea is the main agent of chestnut nut rot in Switzerland. Phytopathol Mediterr 54(2):199-211. https://doi.org/10.14601/ Phytopathol_Mediterr-14712

Lione G, Danti R, Fernandez-Conradi P, Ferreira-Cardoso JV, Lefort F, Marques G, Meyer JB, Prospero S, Radócz L, Robin C, Turchetti T, Vettraino AM, Gonthier P (2019) The emerging pathogen of chestnut Gnomoniopsis castaneae: the challenge posed by a versatile fungus. Eur J Plant Pathol 153:671-685. https://doi.org/10. 1111/ppa.13451

Lione G, Giordano L, Sillo F, Gonthier P (2015) Testing and modelling the effects of climate on the incidence of the emergent nut rot agent of chestnut Gnomoniopsis castanea. Plant Pathol 64(4):852-863. https://doi.org/10.1111/ppa.12319

Maresi G, Oliveira Longa CM, Turchetti T (2013) Brown rot on nuts of Castanea sativa Mill: an emerging disease and its causal agent. IFOREST 6(5):294-301. https://doi.org/10.3832/ifor0952-006

Montealegre J, González S (1986) Hongos causantes de pudriciones en frutos de Castanea sativa Mill. Simiente 56(3-4):166-169

O’ Donnell K, Kistler HC, Cigelnik E, Ploetz RC (1998) Multiple evolutionary origins of the fungus causing Panama disease of banana: concordant evidence from nuclear and mitochondrial gene genealogies. Proc Natl Acad Sci USA 95(5):2044-2049. https://doi. org/10.1073/pnas.95.5.2044

Shuttleworth L, Liew ECY, Guest D (2012) Gnomoniopsis smithogilvyi sp. nov. Fungal Planet Description Sheets 107-127. Persoonia 28:138-182. Pers Mol Phylogeny Evol Fungi 28:42-43. https:// www.ingentaconnect.com/contentone/nhn/pimj/2012/00000028/ 00000001/art00011

Shuttleworth LA, Guest DI, Walker DM (2018) The fungus the Code and the mysterious publication date: why Gnomoniopsis smithogilvyi is still the correct name for the chestnut rot fungus. IMA Fungus 9(2):A78-A79. https://doi.org/10.1007/BF03449443

Shuttleworth LA, Liew ECY, Guest DI (2013) Survey of the incidence of chestnut rot in south-eastern Australia. Australas Plant Pathol 42(1):63-72. https://doi.org/10.1007/s13313-012-0170-

Smith H, Ogilvy D (2008) Nut rot in chestnuts. The Australian Nutgrower 2:10-15

Trifinopoulos J, Nguyen L-T, von Haeseler A, Minh BQ (2016) W-IQTREE: a fast online phylogenetic tool for maximum likelihood analysis. Nucleic Acids Res 44(W1):W232-W235. https://doi.org/ 10.1093/nar/gkw256

Washington WS, Hood V, Stewart-Wade S (1999) Phomopsis castanea, a seed-borne endophyte in chestnut trees. Aust J Bot 47(1):77-84. https://doi.org/10.1071/BT97023

White T, Bruns T, Lee S, Taylor J, Innis M, Gelfand D, Sninsky J (1990) Amplification and direct sequencing of fungal ribosomal RNA genes for phylogenetics. In: Innis MA, Gelfand DH, Sninsky JJ, White TJ (eds) PCR - Protocols and Applications - A Laboratory Manual, vol 31. Academic Press, New York, pp 315-322

\section{Declarations}

Conflict of interest The authors have no conflict of interest. 